\title{
INFORMAÇÃO E TRABALHO NO CAPITALISMO CONTEMPORÂNEO
}

\author{
MARCOS DANTAS
}

Se a "racionalidade moderna foi construída contra a simplificação obscurantista de que "ver é compreender", conforme Genro (2003: 1), dois conflitos sócio-culturais entrelaçados encontram-se nos alicerces dessa construção: $i$ ) Sociedade civil (esfera pública) vs. Estado (aristocrático-absolutista); ii) Conhecimento produtivo vs. Conhecimento especulativo.

Nos dois conflitos, a chamada "burguesia", ou as classes urbanas que se organizavam em torno da produção material e do comércio, ocupava um dos pólos - o da sociedade civil e o do conhecimento produtivo. No outro, encontravam-se as velhas forças sociais herdeiras do feudalismo e a grande burocracia do Estado absolutista.

Ao longo dos dois ou três últimos séculos da história, tendo sido completamente derrotado o campo pré-moderno, os pólos vencedores daqueles dois conflitos (ou seja, o campo "burguês") passaram por mudanças estruturais, mudanças estas que caracterizam as várias etapas vivenciadas pelo modo capitalista de produção, no curso de sua evolução. O objetivo deste artigo é apresentá-las e discutílas.

O conceito de "etapa" surge no marxismo a partir da famosa idéia de Lenin quanto ao imperialismo ser uma nova e última etapa do capitalismo. Poucos autores, porém, aprofundaram o conceito. Podemos, aqui, nos remeter a Kondratieff, economista marxista soviético, falecido em 1930; ou ao nosso contemporâneo Giovanni Arrighi (1996), cuja obra se fundamenta em Marx e Braudel. Ambos demonstram ser possível e necessário estudar e compreender a evolução do capitalismo para além dos seus ciclos curtos de expansão e crise econômica. Estes ciclos, que se sucedem regularmente em períodos de cinco a dez anos (e seriam os únicos que 
Marx poderia examinar e tentar compreender à sua época), estão contidos em períodos maiores de expansão e crise que somente a vivência e a experiência de um tempo histórico maior, visto pelo retrovisor, permitiriam identificar, estudar e compreender. Estes períodos maiores constituem $c i$ clos longos, como os definiu Kondratieff (apud Bessant, 1990; apud CSE Microelectronics Group, 1980). Podem durar entre 30 a 50 anos, isto é, quase o tempo de vida útil de um indivíduo. ${ }^{1}$ Em Arrighi, conforme o seu método e critérios, podem durar pouco mais de século.

Diferentemente dos ciclos curtos, cujas possibilidades de expansão, crise e recuperação estão relacionadas às condições da moeda, do crédito e da renda (donde as suas crises seriam crises de realização, ou de "subconsumo"); os ciclos longos se definem por um conjunto de condições sistêmicas que tanto permitem décadas de expansão econômica e melhoria geral das condições de vida e consumo dos trabalhadores (num processo que abarca vários ciclos curtos de expansão e crise); quanto acarretam, a partir de certo ponto, décadas de retração econômica e derrocada geral das condições de vida e consumo dos trabalhadores (igualmente ao longo de muitos ciclos curtos de expansão e crise). Essas condições sistêmicas envolvem, articuladamente, i) um grupo de indústrias e tecnologias que "puxa" o desenvolvimento; ii) disponibilidade de certas matérias-primas e recursos naturais; iii) condições gerais da mão-de-obra; iv) arranjos políticos e institucionais que presidem os pactos e contratos econômicos e sociais; e ainda outras.

Os ciclos longos passam por períodos de germinação, crescimento, amadurecimento, decrepitude e, finalmente, extinção e superação. Germinam ainda no interior de um ciclo em decrepitude. Extinguem-se, quando já há um outro ciclo em crescimento. Logo, o que definirá uma crise sistêmica de um ciclo é justamente um acúmulo de problemas afetando, em um mesmo momento histórico, um dado regime de acumulação. A saída da crise se dá quando o capitalismo logra encontrar, após anos de estagnação relativa, uma nova fronteira de acumulação que possa substituir aquela, já superada.

1 Kondratieff, em sua época, identificou pelo menos três grandes ciclos: i) 1770-1830: primeira revolução industrial (indústria de fiação movida a roda hidráulica); ii) 1830-1880: segunda etapa da primeira revolução industrial (indústria têxtil movida a vapor); iii) 18801940: segunda revolução industrial (indústrias metal-mecânicas, químicas e motores elétricos ou a explosão). Usando o seu método, podemos falar em um quarto ciclo, apoiado na indústria de consumo de massa (1940-1970) e em um quinto ciclo que estaria ainda em sua fase ascendente, correspondendo à atual "revolução da informação". As datas são evidentemente aproximadas, mas necessárias à periodização. 
Um segundo arcabouço teórico que necessitamos recuperar para uma clara compreensão das idéias que se seguem, trata da teoria do valor, conforme formulada por Marx. É curioso como o debate da esquerda, e o marxista em particular, abandona essa questão central, em seus esforços para entender os tempos atuais, ou então insiste em examiná-la de um modo muito tradicional, quase reverencial, contornando qualquer investigação revisora. A teoria do valor, todos sabemos, se apóia no conceitochave de mais-valia. Mas esta, por sua vez, se nos é apresentada, nos manuais de marxismo e em não poucas obras mais sérias, na sua formatação mais simplória, como uma espécie de corvéia industrial, na qual o operário trabalharia um tempo extra, como um servo medieval, além daquele necessário à sua subsistência. Embora, evidentemente, este seja um aspecto da mais-valia, conforme apresentada por Marx, não pode mais, nos tempos de hoje, ser entendido como o seu aspecto central. A mais-valia, em Marx, possui três dimensões e somente uma delas expressaria aquela espécie de corvéia (ver $O$ Capital, Livro I, Cap. 15). A segunda dimensão estaria relacionada ao custo da cesta de subsistência do trabalhador, algo que, no século XIX, não iria muito além da alimentação pobre e do vestuário simples mas que, hoje em dia, inclui televisão, geladeira, automóvel, turismo de férias, umas tantas outras coisas que tornam algo problemático insistir em determinar o valor de troca da força de trabalho pelo seu custo de subsistência.

Haverá ainda uma terceira dimensão da mais-valia, cuja compreensão será fundamental para entendermos o capitalismo desta nossa época: a intensificação do tempo (Dantas, 2001a). Em Marx, o tempo é um elemento essencial no processo de valorização. Para se valorizar, o capital necessita reduzir os tempos de produção e de circulação. "Economia do tempo, a isto se reduz afinal toda a economia", escreveu Marx nos Grundrisse (Marx, 1971: Vol. I: 101). É uma equação simples: o investimento adiantado apenas será recuperado depois de cumpridas todas as etapas de produção da mercadoria, de sua venda e do retorno do dinheiro obtido. Quanto mais tempo levar este ciclo total, mais o investimento inicial estará sendo corroído pelos juros, pela inflação, pelos azares da natureza ou acidentes da técnica etc. Quanto menos tempo durar esse ciclo, mais rapidamente o capital acrescido poderá voltar à produção e tornar a crescer.

$\mathrm{Na}$ produção, a redução dos tempos depende da natureza dos materiais e das tecnologias disponíveis. Há um tempo incomprimível exigido por cada material em processamento, para transformar esse material no valor de uso desejado. As tecnologias - isto é, o conhecimento para 
a produção - podem diminuir esse tempo, até um certo ponto. Mas não podem reduzi-lo a quase zero. Ao contrário: a obtenção de cada unidade de um produto material final qualquer consome sempre entre algumas dezenas de minutos a muitas horas, desde o momento em que as matérias-primas e insumos começam a ser transformadas pelas máquinas, até o momento em que o produto ganhou a sua forma definitiva, adequada ao seu uso.

$\mathrm{Na}$ circulação, além de todos os azares a enfrentar (crises econômicas, desastres naturais ou técnicos etc), o capital, para realizar a mercadoria, necessita superar o espaço entre o local da produção e os mercados. Percorrer o espaço toma tempo. Para reduzir esse tempo, o capital recorre aos meios de transporte e comunicação. Quanto mais evoluídos são esses meios, mais o capital se valoriza na poupança do tempo (Marx, 1983: Livro II, Cap. 5; Marx, 1971: Vol. II, Caderno 5). Aqui, embora a mercadoria material também cubra um certo tempo incomprimível para ser transportada; a mercadoria-dinheiro pode, sob certas formas, ser transportada à velocidade da luz. O telégrafo já fazia isto, no século XIX. O telefone adicionou novos recursos a esse transporte, no século XX. A telemática está permitindo ao dinheiro dar várias voltas ao mundo em nanosegundos, neste limiar do século XXI.

Em suma, a valorização do capital depende, fundamentalmente, menos de uma extensão algo medieval do tempo de trabalho, muito mais da compressão do tempo de trabalho ao instante menor possível, por unidade de produto. Quanto maior for a quantidade produzida em uma mesma unidade de tempo, e vendida na menor passagem de tempo, maior será a valorização e a acumulação. Nessa dimensão intensificada da mais-valia, o custo de subsistência do trabalhador é o que menos importa. Ao contrário, muitas vezes será necessário assegurar-lhe um padrão sofisticado de subsistência para que ele seja capaz de projetar, ou operar, sistemas sofisticados de trabalho que assegurem produzir e vender no menor tempo possível. As mudanças estruturais do capitalismo, ao longo da sua história, como veremos adiante, estão intimamente relacionadas, entre outros aspectos, às distintas qualificações dos trabalhadores necessários, em cada etapa, para poupar tempo de produção e de circulação, em benefício da acumulação de capital. Ou seja, estão mais relacionadas ao valor de uso do trabalho, ou tra balho concreto, conforme este valor é estabelecido pelas necessidades do capital, do que ao valor de troca do trabalho, ou trabalho abstrato.

Este texto se divide em três partes. Na primeira, intitulada "O Passado", discutimos a evolução do capitalismo - e das idéias socialistas ao longo dos séculos XIX e XX. Na segunda - "O Presente" - tratamos do 
capitalismo informacional deste século e sugerimos como uma teoria científica da informação pode nos ajudar a resolver alguns importantes dilemas teóricos. Na terceira parte, sugerimos tópicos para uma nova alternativa.

\section{PARTE I: O PASSADO}

\section{O conhecimento empírico-produtivo}

O conhecimento racional moderno não resultou tão somente de um magnífico movimento intelectual, ocorrido na Europa, a partir dos séculos XVII e XVIII. Ele deve suas origens a uma espécie de aliança entre uma parcela dos filósofos e cientistas de então, com os trabalhadores artesãos que, em suas oficinas, transformavam recursos naturais e energéticos em valores de uso necessários ao consumo humano. Pensadores como Bacon, Leibiniz, Diderot, para citar apenas aqueles mais influentes, buscaram, consciente e declaradamente, conhecer, estudar, modelizar e, quando possível, descrever matematicamente os processos de produção dos artesãos, assim propondo uma crítica radical ao pensamento especulativo de tradição aristotélicoescolástica que negava a experiência empírica como fonte do conhecimento lógico (Rossi, 1989). É dessa "nova ciência”, como aqueles filósofos diziam, que, entre outras ramificações, derivarão Hegel e Marx.

Ao mesmo tempo, então, os trabalhadores, sobretudo os adultos mais experimentados, herdeiros e reprodutores, por um lado, de uma longa tradição empírica tipicamente artesã, também valorizavam, por outro lado, o conhecimento teórico, as habilidades matemáticas, as explicações que a ciência de então lhes podia fornecer (Landes, 1994). Na Inglaterra, por volta de 1850, funcionavam cerca de 700 "institutos mecânicos" e "salões de ciências" destinados às classes trabalhadoras (Hobsbawn, 1997: 235). $\mathrm{Na}$ França, o Estado promovia a disseminação de escolas politécnicas, para onde acorriam filhos de trabalhadores, e Marx faz referência a elas, no capítulo 13 ("Maquinaria e grande indústria") do Livro I d'O Capital. Os grandes inventores da primeira revolução industrial eram quase todos eles operários ou artesãos que logravam introduzir alguma inovação radical nos processos produtivos, a partir dos conhecimentos que detinham desses processos produtivos mesmos: Stepheson, Maudsley, Arckwrite, Watt etc.

A relação entre o trabalho e o capital, naqueles primórdios, não era (aliás, nunca veio a ser) uma mera relação baseada no consumo (pelo capital) de uma força bruta, muscular, de trabalho. E nem era esta a idéia 
que Marx fazia dessa relação - é importante sublinhar isto, pois a tradição marxista o esqueceu. A relação entre o capital e o trabalho dava-se, na verdade, entre agentes dotados de dinheiro e acessos a mercados (mercadores e banqueiros) e agentes dotados de conhecimento para a produção (trabalhadores ou "proletários"). Aqueles organizavam a compra e a venda de mercadorias, isto é, a circulação. Estes organizavam o processo produtivo material, inclusive a divisão de tarefas dentro dele, isto é, a produção. Os operários adultos, ou qualificados, pensavam o trabalho e realizavam as tarefas que exigiam mais habilidade, mais conhecimento, mais responsabilidade. À sua volta, crianças ("aprendizes"), mulheres, emigrantes irlandeses, alemães executavam as tarefas mais repetitivas, mais embrutecidas, o transporte de peças e materiais, o acabamento etc. Os trabalhadores qualificados eram, por isso, também, empreiteiros (Dobb, 1965), e boa parte das fábricas e oficinas funcionava com mão-de-obra que hoje diríamos "terceirizada". Foi esta a realidade fabril e operária que Marx conheceu na Inglaterra dos anos 1850-1860, quando começou a rascunhar o que viria a ser $O$ Capital. O trabalhador ao qual ele nos remete é o operário qualificado, detentor do conhecimento para a produção, que então se empregava, a si e a terceiros, nas fábricas inglesas ainda mal saídas do regime artesanal de trabalho. Mas as mazelas e crueldades desse conflito entre um trabalho ainda semi-artesanal e um regime de intensificação da produção ditado pela acumulação capitalista, estas ele atribuia à lógica do capital, à sua busca por mais-trabalho que lhe alimentasse a mais-valia.

\section{A esfera pública}

Esse trabalhador que, dotado de conhecimento para a produção, vendia para o "burguês" esse conhecimento em troca de recursos (essenciais ou básicos) para produzir e viver, pouco a pouco vai se submetendo a novas regras de relação com o capitalista, muitas das quais o próprio trabalhador implementa, na medida em que, continuadamente, introduz, nas oficinas, novas técnicas de produção, intensivas de trabalho.

No entanto, embora detendo um poder crucial na produção da riqueza, ele estava excluído dos direitos e obrigações da sociedade civil, limitados apenas à esfera pública burguesa, no conceito de Habermas (1986). Ao longo de suas lutas para impor limites à hora de trabalho e melhorar os salários (lutas estas que assumem, não raro, tonalidades violentas e revolucionárias, como em 1848 e 1870), o trabalhador vai se dando conta dos limites da democracia liberal burguesa típica daquela esfera pública e 
começa a lutar pela universalização do direito de voto (Singer, 1999). É nessa época que nascerão, como expressão política de uma classe operária que buscava chegar ao poder através, principalmente, do voto, os partidos social-democratas.

O projeto social-democrata, um projeto sustentado pelas massas operárias européias, era, pois, um projeto de alargamento e efetiva democratização da esfera pública burguesa. Na medida em que isto se desse, a esfera pública perderia sua estreiteza burguesa, relacionada à propriedade, e ampliaria sua dimensão cidadã, ligada aos direitos sociais básicos. Este era, a rigor, o projeto de Marx. No entanto, Marx e muitos dos seus contemporâneos tinham bons motivos para acreditar que tal democratização da esfera pública não se daria por bons modos. A burguesia resistiria, como resistiu, à perda do seu monopólio político. A própria história das revoluções burguesas sugeria que novas revoluções a elas se seguiriam, talvez em moldes parecidos, mas agora dirigidas pela classe operária e voltadas para a construção de uma esfera pública proletária. A Comuna de Paris, neste sentido, seria o maior exemplo da viabilidade e possibilidades de uma tal evolução.

\section{A segunda revolução industrial}

Uma nova revolução industrial, muito pouco estudada e compreendida, ocorrida em fins dos oitocentos e início dos novecentos, viria a modificar por completo as condições do capitalismo, conforme examinadas por Marx. Em muitos e cruciais aspectos, o roteiro da evolução capitalista na direção desta segunda revolução fora antevisto por ele, tanto n'O Capital, quanto nos Grundrisse. Mas em muitos outros, de modo algum Marx poderia ter-se antecipado, nem a isto se proporia. As invenções, por exemplo, da radiofonia ou da telefonia, do motor a explosão e tantas outras estavam além da sua capacidade de imaginação. Sobretudo e principalmente, embora percebesse claramente que o capital se apropriava da ciência, isto é, do conhecimento para a produção detido pelos trabalhadores de seu tempo, Marx não poderia antecipar como o capital organizaria essa ciência para fornecer-lhe valor.

Aquelas grandes invenções revolucionaram os processos produtivos. Estes não dependiam mais do conhecimento para a produção detido por um coletivo operário situado junto às máquinas, mas de um conhecimento científico-técnico detido por um novo tipo de coletivo trabalhador assalariado, situado em um outro espaço fabril, distante das máquinas: o 
trabalhador de "colarinho branco", geralmente engenheiro, mas também economista, sociólogo, ou outros profissionais de formação universitária. Esse trabalhador deriva diretamente daquele operário qualificado dos tempos de Marx (os primeiros engenheiros de produto e de produção eram operários com formação politécnica), mas insere-se, por completo, na lógica capitalista de acumulação, da qual retira, em seu favor, uma parte nada desprezível da mais-valia intensificada geral (Dantas, 2001a).

O processo produtivo, então, se divide em dois espaços socialmente distintos. As atividades de concepção, de desenho, de projeto, se concentram em salas apropriadas, ocupadas por trabalhadores com elevada formação técnica. As atividades de transformação material direta concentram-se no chão-de-fábrica, sendo maciçamente delegadas a sistemas mecânicos bastante sofisticados, no interior dos quais a matéria sofre as transformações que resultarão em $i$ ) produtos acabados, prontos para o consumo final (panelas de alumínio, baldes plásticos, medicamentos etc); ou ii) produtos semi-acabados que ainda demandarão uma fase de mon tagem para que deles se obtenha um produto final. É o exemplo, no caso mais conhecido, da indústria automobilística. Mas, também, no geral, é o que acontece na produção de quase todos os produtos eletro-eletrônicos de uso doméstico.

O processo de transformação material deixou, desde então, de depender diretamente do trabalho vivo: é concretizado pelas máquinas, ou trabalho morto. $\mathrm{O}$ trabalho vivo, o trabalho efetivamente humano, torna-se, como previsto nos Grundrisse, uma atividade de concepção, de projetação, de observação, de controle, de ajustamento ou, por fim, nos casos de montagem, de auxílio às operações dos sistemas de maquinaria. $\mathrm{O}$ trabalho vivo já não é mais uma atividade humana voltada para a produção de mercadorias como mediação necessária à relação com o capital, mas torna-se, conforme antecipado por Marx no Capítulo inédito, um trabalho destinado a produzir diretamente capital. Esta produção se dará através da mobilização de trabalho para gerar patentes de invenção; para desenvolver processos e métodos que reduzem os tempos de produção e circulação; para criar ou expandir mercados por via do marketing, do crédito etc. Assim, consuma-se a projeção de Marx: o trabalho é subsumido ao capital, isto é, submetido e incorporado ao capital (Marx, s/d). A velha clara distinção econômica, social, cultural entre mercadores e trabalhadores desaparece (Gorz, 1982). Mas esse trabalho que, agora, é corpo do capital, distingue-se socialmente em dois grandes campos: $i$ ) um grande conjunto de trabalhadores assalariados que se incorpora por inteiro à produção e ao modo de vida capitalista 
(os "colarinhos brancos"); e ii) um outro conjunto muito maior de trabalhadores que nessa produção e modo de vida se incorpora apenas parcial e pobremente (os "operários", ou "colarinhos azuis"). É este segundo conjunto de trabalhadores que se julgará herdeiro da tradição de lutas proletárias do século XIX e fornecerá a base social para os partidos social-democratas e comunistas, na Europa e no mundo, ao longo do século XX.

Aquilo que vulgarmente se entende por marxismo, conforme codificado por Kaustski e seus seguidores, inclusive Lenin, fornecerá a teoria e a ideologia dessa social-democracia, em suas muitas ramificações, das reformistas às revolucionárias (Hobsbawm, 1986). Mas esse marxismo, e sua social-democracia, não penetram nos Estados Unidos, a potência líder da segunda revolução industrial. É que, aqui, entre outros fatores, cerca de 20 milhões de imigrantes, na sua maioria europeus, nos fins do século XIX e primeiras décadas do século XX, forneciam, aos novos trabalhadores qualificados, isto é, aos engenheiros, a mão-de-obra desqualificada que, nos tempos de Marx, era fornecida, aos trabalhadores "adultos", pelas crianças e mulheres. Para as tarefas de montagem, de transporte de materiais, de inspeção simples e ainda outras que não exigiam muito conhecimento ou discernimento, e nem estavam relacionadas à transformação material imediata, os imigrantes constituíam força de trabalho ideal, inclusive porque acorreram ao Novo Mundo sonhando em fazer a América, não em fazer a revolução... Eles precisavam apenas aprender a trabalhar "direito": ensinar-lhes a trabalhar, conforme os ritmos e as exigências da acumulação capitalista, é o que se proporão a fazer o ex-metalúrgico Frederick Taylor e os seus seguidores. Dentre estes, um certo Vladimir Ilitch Ulianov, mais conhecido por Lenin, que, depois de tomar o poder na Rússia, descobrirá que o operário russo, agora soviético, não passava de um recém-camponês ignorante e analfabeto, ao qual se deveria adestrar para o trabalho industrial através dos mesmos métodos de Taylor (Lenin, 1980).

O projeto taylorista, ao qual Henry Ford e sua linha de montagem móvel dariam contornos maiores e definitivos, tinha, consciente e declaradamente, um amplo alcance social: visava incorporar aos padrões capitalistas de produção e consumo, uma enorme massa de milhões de pessoas que viviam à margem daqueles padrões, mas desejavam a eles aderir ("fazer a América"). As invenções de Eastman, Edison, Westinghouse, tantos outros, bem como os novos processos de produção introduzidos por Taylor, Fayol, Ford e seus contemporâneos, criavam um mercado capitalista para consumo de capital, neste mercado incorporando, tanto na ponta da produção quanto na do consumo, um novo tipo de trabalhador fabril, 
homogeneizado e massificado. O consumo das classes trabalhadoras ("colarinhos brancos" ou "azuis") começava a incorporar novos ítens que pouco teriam a ver com subsistência, como assim o entenderia Marx, mas muito estavam relacionados às exigências da acumulação: para continuar crescendo, o capital inventava produtos e novas indústrias, nisto necessitando também inventar, via publicidade, os seus respectivos consumidores. Tugán-Baranovski, e não Rosa Luxemburgo (necessitada de demonstrar um "subconsumo" que lhe permitiria crer até a morte em uma revolução iminente), seria quem mais se aproximaria da compreensão dessas novas realidades emergentes do capitalismo (apud Mazzucchelli, 1985; apud Sweezy, 1982).

Diante das dificuldades de reter em suas fábricas, por um longo tempo, homens submetidos a um ritmo escorchante de trabalho, Ford elevou-lhes os salários de dois para cinco dólares a hora, garantindo-lhes, também, oito horas de jornada. Tornou-se um herói das massas, e um exemplo a ser seguido pelos seus concorrentes. A sua política, e de outras big corporations, dava aos trabalhadores renda e tempo livre necessários ao consumo de massa. Os sucessores de Taylor, afastando-se do autoritarismo deste, perceberam, por sua vez, que os seus métodos eram melhor aceitos quando negociados com as representações sindicais (Noble, 1979). Todos pareciam ganhar: a produtividade crescia, os lucros aumentavam, os empregos se expandiam, os salários subiam, as vendas se ampliavam, os lucros aumentavam, os empregos se expandiam, os salários subiam...

Um outro traço fundamental desse padrão de acumulação seria o modo de organização das unidades produtivas. Uma imensa burocracia, dentro de cada grande empresa, passa a ser empregada para gerar, processar e comunicar a massa de informação necessária à condução dos negócios e à gestão da produção. Ao mesmo tempo, cada grande empresa tende a concentrar em um mesmo espaço o maior conjunto possível de atividades industriais de transformação e montagem: desde o preparo das matériasprimas básicas até a montagem do produto final. O melhor exemplo é o complexo de Baton Rouge, da Ford. Mas foram os soviéticos que imortalizaram o nome que identificaria esses complexos: kombinat.

Há uma lógica nessa organização: poupar tempo. O problema da empresa já não é tanto o da transformação, entregue aos sistemas de maquinaria e aos mínimos tempos irredutíveis de processamento, conforme a natureza de cada material processado. O problema da empresa é o de circulação, isto é, de movimentação de materiais semitransformados ao longo da montagem final; de movimentação dos produtos para os seus 
mercados de consumo; e de transporte de informação entre as várias etapas de produção e comercialização. Dada as possibilidades permitidas pela base técnica da circulação nas primeiras décadas do século XX (os meios de transporte de mercadorias ou de informação então disponíveis), concentrar o máximo de atividades produtivas possíveis no menor espaço disponível funcionava como eficiente estratégia para reduzir os tempos de circulação. No dizer de Chandler (1977), as corporações cresciam atrás de "economias de velocidade". Marx diria "economia de tempo". Além do mais, desta lógica resultava a geração de milhões de postos de trabalho, seja na fábrica, seja no escritório, proporcionando renda e consumo aos trabalhadores.

A crise de 1929 abriu caminho para tornar também o Estado um ator econômico direto. Ele assume o papel de i) mobilizar capitais para investimentos de lenta maturação; $i$ ) financiar a fundo perdido os gastos na formação e manutenção de recursos humanos (educação, saúde etc); iii) regular e arbitrar os conflitos sociais e econômicos. O Estado era o elemento que faltava à consolidação do pacto social que o taylor-fordismo começara a construir nos anos 1910, nos Estados Unidos, de onde se expandiria para o resto do mundo capitalista avançado.

Nenhum acordo se efetiva sem negociações, às vezes árduas. O grande acordo social alcançado entre as direções das grandes corporações estadunidenses, as direções dos grandes sindicatos de trabalhadores e o comando político dos Estados Unidos, nos anos 1910-1940, não foi firmado por decreto, nem da noite para o dia. Resultou de duras negociações, não raro marcadas por greves e até momentos de violência operária ou policial. Às mentes e olhos contemporâneos e participantes, esses conflitos poderiam parecer expressões concretas de "lutas de classe" e, para muitos, degraus necessários ao avanço da revolução. Hoje, olhando pelo retrovisor, sabemos que exprimiam, de fato, momentos de uma grande negociação histórica entre grupos sociais poderosos, que disputavam fatias maiores ou menores da mais-valia social geral. $\mathrm{Na}$ verdade, os arreganhos de parte a parte, quando necessários, se faziam conforme as regras e nos limites de um consenso fabril de fundo, a respeito do objeto verdadeiramente em disputa: a repartição da maisvalia intensificada (Burawoy, 1979). Disto resultou aquilo que a Escola Francesa da Regulação viria a denominar pacto fordista (Harvey, 1996) que teve, entre suas características fundamentais, a busca por incorporar, ao máximo possível, as massas humanas aos padrões capitalistas de produção e consumo. 


\section{A esfera social semipública}

A incorporação, pelo capital, do conhecimento para a produção, através da adesão aos modos de produção e de consumo tipicamente capitalistas de parcela, cada vez maior, dos trabalhadores responsáveis pela produção desse conhecimento, foi acompanhada de uma ampla mudança estrutural na esfera pública (Habermas, 1986). À esfera pública burguesa não se sucede uma esfera pública democrática e cidadã, conforme teriam sonhado os combatentes do sufrágio universal, no final do século XIX. Da esfera pública burguesa (democrático-liberal) nasceu uma esfera social semipública (democrático-estatal), na qual aparelhos de representação assumem a tarefa de exprimir e negociar os diferentes e contraditórios interesses presentes na sociedade. $\mathrm{O}$ ideal da presentação cidadã (que os sovietes congressuais ainda imaginaram poder sustentar) é falsificado pela realidade prática da representação do cidadão, assumida pelos partidos políticos, pelos sindicatos, pelos próprios organismos de Estado, pela imprensa de massa etc. A sociedade se divide entre um público (restrito e elitizado) que produz cultura (nas formas política, científico-técnica, artística etc); e um público (amplo e massificado) que apenas recebe cultura (sobretudo, através da imprensa, da radiodifusão, do cinema).

A organização dos meios de comunicação que nascem no bojo da segunda revolução industrial e a própria reorganização pela qual passa a imprensa escrita nessa mesma época, expressam claramente essas novas condições sociopolíticas. A partir da segunda metade do século XIX, acompanhando a expansão numérica daquele novo tipo de trabalhador desqualificado que a segunda revolução industrial vinha criando e empregando, surge, inicialmente nos Estados Unidos, a imprensa de massa como nova fronteira dos investimentos capitalistas, logo sendo organizada para a obtenção de receitas e lucros. Nos anos 1920, a recém-nascida radiodifusão viverá, nos Estados Unidos, evolução similar: será organizada para fornecer ao maior número possível de rádio-ouvintes, notícia e entretenimento, através dos quais veiculará publicidade capaz de lhe permitir auferir receitas e lucros. Ela se expande juntamente com outras novas indústrias voltadas para a produção cultural e o entretenimento. Adorno e Horckheimer (1985) lhes captaram a essência, em estudo clássico: a radiodifusão, o cinema, a indústria fonográfica etc buscavam fornecer um tipo de informação, conhecimento e cultura que permitisse ao trabalhador rotinizado e massificado reproduzir, em seu tempo livre, as mesmas práticas repetitivas e padronizadas às quais se submetia em seu tempo de trabalho - sem o quê mergulharia em um quadro psíquico esquizofrênico. 
As indústrias culturais eram, também, fabricantes de mercado: criavam e introduziam hábitos de vida e modos de pensar que tornavam-se base cultural e ideológica necessária à absorção, pelas massas, das mensagens publicitárias que movimentavam as vendas e sustentavam os lucros. Mais uma vez, tratava-se do capital produzindo consumo capitalista e se expandindo graças a esse consumo. Uma produção e um consumo apenas possível porque toda a massa trabalhadora, em que pese as diferenças de renda e padrão de vida entre os "colarinhos brancos" e os "colarinhos azuis", encontrava-se plenamente subsumida ao capital - a ele aderira. Repetindo: os conflitos sociais tornam-se intracapitalistas, conflitos a respeito da repartição, entre os diversos estamentos de trabalhadores, da mais-valia geral que ora se expande, ora se contrai. Que, para muitas lideranças, embora sinceras, esses conflitos, sobretudo quando agudos, parecessem prenunciar uma revolução, era característico desses tempos e das utopias próprias a cada época histórica. E quando as massas não respondiam aos apelos revolucionários, não faltavam explicações expiatórias: "baixo nível ideológico"; "aristocracia operária"; "elevar as lutas do econômico ao político"; "papel das vanguardas"... Que fazer?...

\section{PARTE II: O PRESENTE}

\section{A terceira revolução industrial}

A denominada "terceira revolução industrial" ou "revolução da informação" deve o seu impulso inicial à Segunda Grande Guerra, quando vultosos recursos financeiros e equipes científicas da mais alta qualificação foram mobilizados para desenvolver máquinas capazes, tanto de efetuar rapidamente cálculos muito complexos, quanto, principalmente, de proces sar a informação: reunir dados de diferentes origens, postos em forma numérica (binária) e associá-los conforme algoritmos pré-definidos. Ao final da guerra, se consolidara, nos Estados Unidos, uma pequena mas muito influente comunidade científico-militar que colocou para si mesma, como primeiro problema pós-Guerra a resolver, a busca de motivos e fundos financeiros (ou fundos financeiros e motivos) para dar sequiência às suas pesquisas e... seus empregos (Noble, 1986; Bretton, 1991).

A solução para tal problema veio de três demandas sociais concomitantes:

i) As Forças Armadas estadunidenses (isto é, o Estado) necessitavam de equipamentos e componentes cada vez mais sofisticados para 
sustentar e ampliar sua liderança bélica no Ocidente e sua disputa militar com a União Soviética;

ii) Os sindicatos operários haviam adquirido um enorme poder no chão-de-fábrica agudizando os conflitos políticos e econômicos com as instâncias gerenciais. Estas perceberam que os servo-mecanismos nascidos da investigação acadêmico-militar podiam ser potenciais substitutos da massa cada vez mais exigente de trabalhadores taylorizados, e passaram a estimular pesquisas que viabilizassem utilizá-los nas fábricas;

iii) As organizações comerciais e financeiras empregavam enormes e cada vez menos produtivas massas de trabalhadores de escritório, no tratamento e comunicação de informação, necessitando de equipamentos capazes de automatizar essas atividades. Os primeiros computadores civis foram, com efeito, fabricados por empresas especializadas em materiais de escritório (Sperry, IBM, NCR etc) e vendidos a grandes cadeias de lojas comerciais.

Aevolução da informática foi lenta e, no início, pouco percebida. Vivia-se o auge dos "gloriosos trinta" e os computadores e sistemas eletrônicos não eram ainda uma necessidade tão premente, exceto para o complexo industrial-militar estadunidense. Houve tempo, pois, para que fossem evoluindo, amadurecendo, crescendo em complexidade aliada à facilidade de uso, e baixando de preço, progressivamente. No final da década 1970, os Estados Unidos ostentavam uma enorme dianteira nessa nova tecnologia e indústria, comparativamente a outros países capitalistas avançados. Percebendo os riscos econômicos, militares e até culturais que essa dianteira lhes criava, países como a França, a Alemanha, o Japão, alguns outros, deram início a programas governamentais estratégicos visando a recuperação do atraso (Breton, 1991; Mizrahi, 1986). O mais exitoso desses programas foi, sem dúvida, o do Japão: graças ao seu investimento em larga escala na informática, na automação e nas telecomunicações digitais, o país, destruído na Segunda Guerra, reocupou o seu lugar entre as maiores potências industriais do mundo. Também a França, a Alemanha e alguns outros países europeus lograram assumir posições de destaque e liderança mundiais em diversos segmentos de fronteira nas indústrias do complexo eletrônico.

Quando, devido a fortes investimentos estatais, aliados à mobilização da comunidade científica e de investidores financeiros privados, a informática mostrava-se finalmente madura para se disseminar social- 
mente, eclodiu a definitiva grande crise sistêmica do "fordismo". Seus marcos foram a "crise do petróleo" e a seguinte "crise do dólar". Suas causas ainda provocam polêmicas entre os pesquisadores e intelectuais mais sérios, e sugerem muitos slogans pouco criativos e inconseqüentes na militância esquerdista avessa aos estudos. Na verdade, apesar de alguns bons ensaios, como o de Harvey (1996) ou o de Arrighi (1996), pouco se investiga sobre os motivos do esgotamento do regime. Muitos intelectuais acharam melhor começar a formular chaves explicativas para o novo sistema emergente, do que tentar explicar a crise daquele que se esgotou. Castells (1998) é o melhor exemplo, nem por isso a melhor análise.

$\mathrm{Na}$ carência de pesquisas empíricas e formulações teóricas mais consistentes, arrisquemos algumas hipóteses de interpretação. O padrão "fordista" entrou em crise porque:

i) Esgotou a sua capacidade para seguir incorporando, tanto nos países centrais quanto nos periféricos, as massas de trabalhadores desqualificados necessárias ao trabalho taylorizado e ao consumo capitalista padronizado. Nos países centrais, a população trabalhadora subalterna conquistou, no geral, bons níveis de educação e consumo, não se prestando mais, salvo a um alto custo relativo, à realização de trabalhos intelectualmente pobres. Nos paises periféricos, uma grande parcela da população, por razões econômicas mas, sobretudo culturais, não teve como ser incorporada aos padrões capitalistas de produção e consumo, sendo, por isso, crescentemente excluída do próprio processo civilizatório.

ii) Quanto mais enriquecia o, no dizer de Perez (1986), "conteúdo informacional dos produtos", através da ciência e tecnologia, das inovações de produto e processo, da complexidade técnica, do marketing, da clientelização etc, mais o capital necessitava reduzir os ciclos de vida desses produtos, assim impondo-se flexibilizar processos produtivos, tanto em escala, quanto em escopo e, principalmente, orientar-se para um mercado e, mesmo, produzir um mercado crescentemente sofisticado.

iii) Quanto mais estendia, mundo a fora, as suas linhas de produção e comercialização (através das companhias multinacionais), mais tornavam-se onerosos, em custos de espaço e de tempo, os chamados "custos de transação", isto é, em termos marxianos, os custos inerentes aos tempos de circulação consumidos na realização do valor da mercadoria. As "economias de velocidade" passíveis de serem obtidas pela grande corporação capitalista burocrática centralizada chegaram aos seus limites. 
O longo ciclo depressivo iniciado em meados dos anos 1970 parece ter chegado no fundo do poço ao final da década de 1980, e dado sinais de superação nos anos 1990, quando a economia estadunidense manteve-se em ritmo de crescimento por quase dez anos. No entanto, ainda é cedo para reconhecermos já se ter iniciado um novo longo ciclo de desenvolvimento. Mas é possível delinearmos alguns aspectos básicos do que virá a ser esta nova etapa da história capitalista.

Primeiro aspecto. Desapareceu, graças às redes telemáticas, a necessidade de a organização capitalista concentrar recursos humanos e materiais no menor espaço territorial possível. As "economias de velocidade" que se podiam obter aí, com conseqüentes barateamentos nos “custos de transação", podem ser facilmente substituídas pelas economias proporcionadas pelos sistemas de comunicação. Isto é: já não é mais necessário empregar uma grande burocracia para gerar, organizar e transportar a informação através dos vários setores de uma firma qualquer. Boa parte dessa informação agora é organizada e transportada através de máquinas. $\mathrm{O}$ trabalho vivo que precisava ser empregado, nos tempos do "fordismo", para a realização dessas atividades, cedeu seu lugar a trabalho morto. E por isso também, a empresa capitalista pode espalhar-se no espaço, segmentar-se em muitas subempresas, focar cada uma das suas muitas atividades em muitas unidades de capital (firmas) especializadas. Daí o fenômeno conhecido como "terceirização" que, em novo estágio, recupera o padrão de relações de trabalho típico da Inglaterra têxtil.

Segundo aspecto. O consumo capitalista tende a não mais se expandir, mas a se intensificar. Cessa a expansão do mercado de massas. Com base na alta renda, elevado grau de informação e sofisticação de gostos de uma parcela nada desprezível, numericamente falando, de consumidores, espalhada nos países centrais e nos bolsões desenvolvidos dos países periféricos, será possível sustentar um padrão de produção calcado em economias de escopo e na obsolescência acelerada. $\mathrm{O}$ eixo motor do investimento produtivo será (já é) a cultura, logo as indústrias mediáticas e de consumo.

Como a produção e o consumo necessitam de uma classe trabalhadora de elevado padrão educacional, cultural e material, os investimentos se concentrarão (já estão se concentrando) nos países capitalistas avançados e em poucos bolsões desenvolvidos dos países periféricos. A classe trabalhadora, aí, sequer se reconhece enquanto tal, mas enquanto "consumidores", ou "profissionais", ou "intelectuais" etc. Mesmo os 
operários fabrís, cujo número diminui a olhos vistos num fenômeno já há muito identificado pela literatura (Bell, 1976; Touraine, 1988), adquiriram hábitos e expectativas de vida próprios da classe média, ainda que se situando nos níveis mais baixos da escala de renda e consumo.

No entanto, como é óbvio, nem desapareceu uma imensa massa de seres humanos que precisa trabalhar para sobreviver, nem desapareceram muitas atividades que ainda requerem mão-de-obra desqualificada. Essa massa humana tenta migrar para os países capitalistas centrais, onde se emprega em atividades subalternas e, em alguns casos, aviltantes: entregadores, faxineiros etc. Uma outra parte encontra emprego em suas próprias regiões de origem, se nelas se instalam fábricas de montagem ou confecção a serviço de grandes corporações globais. A automação e a robotização ainda não avançaram por todos os ramos da indústria. Por isso, o baixíssimo custo da mão-de-obra ou algumas vantagens locacionais, além de incentivos concedidos por governos corruptos, atraem empresas para a periferia do sistema mundial, onde instalam unidades de montagem e confecção. E nem falemos do crescente mercado de trabalho gerado pelo tráfico de drogas, pelos mercados "cinzas" etc.

Terceiro aspecto. As indústrias que impulsionam esta nova etapa são essencialmente calcadas no processamento e comunicação da informação: informática e telecomunicações, biotecnologia, cultura etc. Embora o processamento e comunicação da informação também fossem essenciais ao "fordismo" (a rigor, sempre foi constituinte do trabalho humano), nele cabia um grande conjunto de atividades, aquelas rotineiras e repetitivas, que pareciam desprovidas de maior conteúdo informacional, logo pareciam demandar apenas esforço físico humano. Amaior parte dos empregos era gerada aí - e dos problemas sociais, também. Ao contrário, embora estratégicos, os laboratórios industriais empregavam um conjunto relativamente pequeno de trabalhadores científicos: grandes empresas como a Du Pont ou a AT\&T, não ocupavam, nos anos 1930, mais do que 1.500 ou cinco mil cientistas e engenheiros em seus laboratórios, contra dezenas de milhares de outros trabalhadores em suas demais atividades produtivas e comerciais.

Na nova etapa do desenvolvimento capitalista, as indústrias que "puxam" a recuperação, geram empregos diretos principalmente nas atividades de alto conteúdo intelectual: $\mathrm{P} \& \mathrm{D}$, marketing, alguns processos fabris sofisticados. Entre os seus empregados, os de baixa escolarização são minoria, ou não existem. Nestas indústrias, as demais atividades necessárias à fabricação e comercialização do produto, são "terceirizadas". Muitas dessas 
atividades são transferidas para os países pobres da periferia: México, América Central, Sudeste Asiático, em parte o Brasil. Redefine-se, assim, a divisão internacional do trabalho. Nos países centrais concentram-se as atividades mais criativas e bem remuneradas, transferindo-se para a periferia as atividades mais rotineiras, repetitivas e mal remuneradas.

Também modificou-se a natureza e práticas das atividades de laboratório. Nos tempos heróicos do "fordismo", a maior e mais decisiva parte das inovações decorriam de experiências que muito dependiam da tentativa e erro, da descoberta um tanto casual, do experimentalismo empírico. A ciência dos laboratórios industriais tinha muito de artesanal. As invenções de Edison, Tesla, Marconi, Otto, dentre outros, pouco devem, diretamente, ao conhecimento científico da época, embora a ele pudessem se remeter indiretamente, em especial quanto aos métodos de trabalho e às lógicas de raciocínio. Ao contrário, descobertas tipicamente científicas levavam vinte, trinta anos ou mais para se transformarem em tecnologias industriais, a exemplo da radioatividade, ou da física do estado sólido. A distância entre a universidade e a indústria ainda era grande.

Já as novas indústrias desta "terceira revolução industrial" nascem completamente determinadas por teorias científicas, e se baseiam em uma forma de conhecimento que não procede do empírico, embora, claro, não possa deixar de passar, em algum momento (em especial, no momento do mercado), pelo teste da prática. A pesquisa tecnológica já sabe, de antemão, o seu resultado, pois detém alto grau de controle sobre suas premissas teóricas e algoritmos dos cálculos. A taxa de incerteza, embora sempre presente, é pequena, até porque, cada vez mais, a própria pesquisa científica stricto sensu está voltada para a descoberta de aplicações práticas - leia-se mercantis - do conhecimento obtido. Disto, não há exemplo mais óbvio que a biotecnologia. A pesquisa científica tornouse, ela mesma, um componente da produção industrial, e a universidade tende a integrar-se à indústria e ao processo de valorização.

Assim completa-se a absorção, pelo capital, do conhecimento para a produção próprio do trabalho, embora, por isto mesmo, incorporando de vez (subsumindo) o trabalhador que segue gerando esse conhecimento. Em seus primórdios, como vimos na Parte I, item 1, o capital empregava o trabalho a ele externo, para dele extrair o conhecimento empiricamente produtivo que se encontrava, através do corpo e mente do trabalhador, em relação imediata com a produção material, localizada na oficina. Ao longo das suas revoluções industriais, o capital veio desenvolvendo o conhecimento cientificamente produtivo, em substituição ao 
empírico, e desenvolvendo, pari passu, em suas várias instâncias, das mais criativas às mais repetitivas, o novo trabalhador necessário para gerar, ou operar, ou apenas introduzir maquinalmente esse conhecimento, na produção material automatizada.

\section{A indústria mediática}

Há, por fim, um quarto aspecto a considerar, além dos três acima: o papel central que assume, nesta etapa, a indústria cultural e mediática. No "fordismo", a indústria cultural era meio de produção de um mercado de consumo de massas - e de um trabalhador massificado. Agora, a indústria cultural está voltada, sobretudo, para a produção do seu mercado e do seu trabalhador (o "artista", o "desportista", o "intelectual mediático", ou o político idem etc). Antes, era um meio necessário para a acumulação nos setores então de ponta, cujas cadeias produtivas desaguavam na produção de bens de consumo de massa. Agora, é ela uma das indústrias de ponta, um dos pólos dinâmicos da acumulação, está entre aqueles setores que põem as demais indústrias a serviço da sua dinâmica e das suas exigências - como o foram o setor têxtil no século XIX, e os químico e metal-mecânico no século XX.

Boa parte da indústria "material" contemporânea deve o seu dinamismo à indústria cultural: não existiriam televisores e toca-CDs, se não existissem novelas, "faustões" e conjuntos musicais. Não se venderiam tantos refrigerantes artificiais, automóveis ou eletrodomésticos, entre muitas outras coisas, não servissem a programação da televisão e do rádio, bem como os hábitos de vida e as idéias supérfluas de tantos artistas, para estimular essas vendas.

Por outro lado, a indústria mediática desvela, mais do que qualquer outra, uma totalmente nova condição da relação entre o capital e o trabalho: na produção artística capitalista, o trabalho fornece um produto indissociável do corpo e da mente do trabalhador que o realiza. O produto do trabalho não é uma mercadoria que, uma vez produzida, possa viajar pelo mundo, ignorando-se quem a fabricou, individual ou coletivamente. No "mercado" cultural, "consome-se" o "artista", seu nome, sua empatia, seu carisma. O trabalho aqui somente tem valor enquanto trabalho concre to, trabalho que encerra as qualificações, as habilidades, o conhecimento de quem o realiza, não mensurável por alguma quantidade de trabalho abstrato. Conclusão, aparentemente paradoxal: o produto capitalista típico desta nova etapa não pode conter valor de troca. 
Já Marx, no seu tempo, sabia que, nos serviços, a exemplo das atividades de um professor ou de uma cantora, o valor de uso do trabalho, função do trabalho concreto, não podia ser medido em termos de valor de troca, função do trabalho abstrato. Por isto, ele excluía essas atividades da teoria (Marx, s/d). No entanto, a evolução do capitalismo, 150 anos depois de Marx, já não nos permite desconsiderar o problema da valorização e apropriação de trabalho concreto irredutível a trabalho abstrato. Trata-se efetivamente de um problema sucitado pela indústria cultural e de muito difícil solução nos termos da teoria ortodoxa, conforme aponta Bolaño (2000). No fundo, este é o problema central de toda a economia da infor mação, em uma sociedade (ainda) apoiada na "mesquinha base" (Marx) do intercâmbio mercantil e da propriedade privada.

Assim como a indústria cultural, toda a indústria apoiada em $\mathrm{P} \& \mathrm{D}$, marcas, mensagens publicitárias, consultorias técnicas etc, acaba essencialmente dependente de um tipo de trabalhador altamente qualificado, cujo produto não se desprende de sua qualificação. O produto desse trabalho não é cambiável no mercado, pois não contém uma régua abstrata de mensuração. $\mathrm{O}$ senso comum dos economistas e do linguajar quotidiano o percebe, ao descrevê-lo todos, como "serviços". São serviços, mas não como o poderia entender Marx, até porque, quase sempre, são realizados coletivamente e, não raro, por trabalhadores assalariados. O nosso problema teórico - e político - central, sem cuja solução continuaremos sem decifrar a Esfinge do capitalismo atual, é justo o de explicar um regime de acumulação que, no seu cerne, caminha para abolir a troca. Exemplo: na indústria de programas de computador, o produto não é vendido, mas licen ciado. O usuário adquire um direito de uso, mas não a propriedade do programa. O licenciador não se desfaz da sua "mercadoria", mas segue licenciando-a para outros e ainda outros usuários interessados. Em muitos outros segmentos econômicos, a assistência técnica e outros "serviços pósvenda" são mais importantes do que a venda em si. Há uma lógica nisso: a lógica do capital-informação.

\section{Teorizando a informação}

A esta altura, para prosseguir, necessitamos definir melhor o que entendemos por informação, palavra que vem se fazendo cada vez mais presente neste texto, sendo já de uso corrente tanto em estudos mais sérios, quanto em literatura de aeroporto. Para compreendermos o que seja informação, precisamos recorrer a uma teoria científica da informação e da 
comunicação, conforme formulada por Shannon (1975), Wiener (1978), Brillouin (1988), Atlan (1992), Bateson (1998), Escarpit (1991) e ainda outros (apud Dantas, 1999; 2001a; 2002). Informação, nessa teoria, é um processo de seleção efetuado por algum agente, entre eventos passíveis de ocorrer em um dado ambiente. Na origem da informação encontra-se, de um lado, sinais físico-energéticos emanados de um objeto ou ambiente qualquer, na forma de vibrações sonoras, radiações elétricas ou luminosas, moléculas odoríferas etc; e, de outro lado, um agente (ou sujeito) capaz de extrair algum sentido, ou orientação, ou significado desses sinais. Por isto, para que ocorra informação haverá sempre necessidade de interação (ou comunicação) entre um sujeito e um objeto, ou sujeito a sujeito. Aqui não importa a forma da informação: sensorial, para o geral do reino animal ou botânico; cultural, no gênero humano. Qualquer que seja a sua forma (e, no meio humano, a informação adquire altíssimo grau de diversidade e complexidade), ela sempre resulta de interação e somente se dá na interação. Daí porque a informação parece adquirir esse aspecto "imaterial" que leva alguns autores a se referirem a uma "economia imaterial", ou "trabalho imaterial" (Lazzarato, 1992). Não há nada de "imaterial" na informação, na medida em que ela emana de fontes materiais e de fenômenos físico-químicos da natureza, sendo processada também por algum agente corpóreo.

Portanto, a informação se situa, se pudermos usar, para efeitos didáticos, alguma metáfora espacial, em uma espécie de sítio intermediário entre a origem dos fenômenos sinalizadores e os agentes que os captam e os processam. Não será nem atributo do objeto, nem do agente, mas será sempre uma relação entre ambos. Sinais sinalizadores não passam de fenômenos físico-energéticos se não existir, no ambiente, algum agente capaz de percebê-los e deles extrair algum sentido ou significado. Na outra ponta, qualquer agente não poderá agir orientadamente, se não estiver apto para perceber e compreender os sinais que emanam do ambiente.

Se o agente é um ser humano trabalhador, essa aptidão para perceber formas, odores, cores, atribuindo-lhes significados que orientarão as decisões que resultarão nas ações destinadas a transformar matérias-primas em produtos úteis, essa aptidão é justamente aquilo que Marx definia como o valor de uso do trabalho. No processo de trabalho, esta "subjetividade" é introduzida na matéria "morta", revolvendo-a, modificando-a, transformando-a em algo novo e necessário ao consumo ou usufruto humano. Por isto, essa "subjetividade", por si só, cria valor (Marx, 1983: Vol. 1: 170-171; Rosdolsky, 2001: 189). A iniqüidade capitalista, para Marx, radica no fato de o trabalhador ter sido posto para trabalhar por um 
tempo muito além do essencialmente necessário para a criação desse valor, assim produzindo mais-valor, além do que necessita para atender às suas necessidades, mas decisivo para as necessidades do capital.

Implica dizer: o trabalho em atividade, o trabalho vivo, é a própria informação em processo, é a própria relação entre o sujeito e o seu objeto no ato de transformação. Trabalhar é informar e se informar (informare, pôr em forma, no latim). Como o processamento de informação dissipa, e não pode deixar de dissipar, as energias do corpo (tal vale, tanto para o trabalho dito "braçal", quanto para o dito "intelectual"), o trabalhador necessita adquirir os elementos que vão lhe permitir recuperar suas energias e repor outras demandas vitais. Este "preço a pagar" pela energia que o corpo dissipa determina o valor de troca do trabalho. Esta era a régua que podia medir o preço da mercadoria força-de-trabalho quando o rendimento do trabalho - isto é, a relação entre a atividade de informar e se informar em função de um quantum resultante de produto - não podia ser muito superior à dissipação máxima de energias durante esse tempo de trabalho mesmo. Na medida em que a intensificação mecanizada e automatizada do trabalho veio permitindo que a atividade de informar e se informar se tornasse, no que diz respeito às dimensões quantitativas do resultado, quase nada dependente da dissipação corpórea de energia e outras demandas vitais, aquela régua perde a sua aplicabilidade. Já o era de difícil aplicação desde quando o resultado do trabalho tornou-se produção de capital para consumo capitalista, descolado das necessidades corpóreas vitais. Em nada se aplica, se o resultado, como acabamos de ver no item 2, acima, passa a ser a ativi dade ela mesma, vale dizer, a própria informação.

A produção informacional convoca o trabalho tanto de quem aparentemente a realiza, quanto de quem aparentemente a usufrui. O produto artístico, por exemplo, não resulta somente da atividade do artista, mas também requer alguma atividade do público, no sentido de entender, absorver, reagir às mensagens que recebe. Por mais banais e idiotas que sejam certas canções que escutamos em programas de auditório da televisão, elas mobilizam a participação e emoções do público porque "qualquer tipo genuino de compreensão deve ser ativo, deve conter já o germe de uma resposta", conforme nos ensina Bakhtin. "Só a compreensão ativa nos permite entender o tema [...] Compreender a enunciação de outrem significa orientar-se em relação a ela" (Bakhtin, 1986: 132, grifo no original). Ou seja, como já o dissemos, a interação entre os agentes é inerente e constitutiva de todo o trabalho informacional. 
Por isto, quando o valor econômico do produto do trabalho encerra-se no seu valor de uso, o capital vê-se na contingência de desenvolver novos mecanismos de realização, para substituir a troca mercantil. Informação não se troca, se compartilha (Caraça, 1993). A solução de Bolaño (2000) para este problema, tendo em si o mérito de perceber o problema e apontar-lhe uma solução, será, porém, parcial. Estudando o "mercado" artístico-cultural, ele sugere que a "audiência" tornou-se a mercadoria de troca dos produtores culturais. A "fidelização da audiência" seria o meio através do qual os produtores capitalistas poderiam exibir um "produto" para a troca com outros agentes (as agências de publicidade, por exemplo). Ora, essa "fidelização da audiência", se é que possível, não gera um produto cambiável, algo que seja transferível a outro, em troca de algo que este outro tenha a dar - como o é da essência da mercadoria. A audiência fiel precisa ser retida pelo seu produtor para que ele possa licenciar, digamos assim, o acesso a ela por parte dos produtores publicitários, semelhantemente ao produtor de programas de computador que licencia o acesso aos seus programas por parte dos usuários. $\mathrm{O}$ que garante àquele produtor cultural exercer este poder de controlar um direito de acesso, não será apenas a fidelização de uma audiência aliás muito volúvel, mas principalmente o controle de algum meio físico de acesso a tal audiência, seja a banda de freqüência espectral, ou o cabo de televisão etc. Na medida em que a audiência somente pode ser atingida através de um canal físico de comunicação, o domínio desse canal passa a ser um instrumento poderoso de açambarcamento das rendas oriundas do trabalho do artista com o seu público.

Qualquer que seja a estratégia de negócios própria a cada uma das diversas indústrias informacionais contemporâneas, o que elas buscam, em essência, é afirmar algum tipo de monopólio sobre a informação da qual extraem as rendas que viabilizam a acumulação. Sendo mais exato, buscam controlar as fontes de informação ou os meios de acesso, quando não ambos. De recurso social, a informação é travestida em mercadoria na verdade, não a informação ela mesma, mas os objetos necessários à realização de algum trabalho informacional, desde os CDs contendo um programa de computador, até calçados esportivos (ditos, "tênis") expondo um desenho característico de alguma marca famosa (Nike, Adidas etc). A matéria aí serve apenas de suporte para a comunicação de alguma informação-valor, e de meio para a apropriação desse valor. $\mathrm{O}$ assim dito proprietário do suporte ou de outros meios de acesso às fontes de informação passa a extrair desse poder uma espécie de renda diferencial similar àquelas analisadas por Marx nos capítulos 39 e seguintes, do Livro III d'O 
Capital. É uma renda monopolista, nascida de um recurso, a informação, que se faz valor - assim como a terra, ou uma jazida mineral - porque, sendo absolutamente essencial à vida social e econômica, só pode ser acessada com o consentimento (devidamente pago) daquele que o açambarcou. A esta nova forma de rendimento, denominamos rendas informacionais (Dantas, 1994; Dantas, 2001a).

Como, no entanto, o valor ainda reside na informação comunicada, vale dizer, no trabalho informacional que põe em relação o produtor e o usuário, e não no suporte utilizado, o capitalismo informacional vê-se diante de uma contradição insolúvel: o valor dessa informação, trabalho concreto, consome-se tão logo o trabalho é efetuado. Não se transfere para a suposta mercadoria. Ninguém conhece melhor este fenômeno do que as empresas produtoras de programas de computador, Microsoft à frente de todas. As cópias, ditas "piratas", dos seus produtos, não raro totalmente gratuitas para os usuários que as adquirem de amigos ou até de sítios na Internet especializados em distribuí-las a qualquer interessado, demonstram empírica e cabalmente como uma "mercadoria informacional" se desvaloriza radicalmente, até se tornar gratuita, tão logo seja dada a conhecer no mercado. $\mathrm{O}$ valor reside, insistamos, na interação, não no suporte. Se podem, os consumidores, fazendo escolhas absolutamente racionais que mereceriam as bênçãos de Adam Smith, obtêm esses suportes a preços marginais próximos a zero, quando não de graça. As cada vez mais draconianas e policialescas leis de "proteção à propriedade intelectual" pouco podem fazer contra essa realidade social. Tais leis, salvo pelos seus efeitos anti-sociais e antidemocráticos, lembram a piada do prefeito de uma cidade interiorana que, desejando construir uma caixa d'água em um ponto abaixo do nível das casas, enviou aos seus vereadores um projeto de lei revogando uma "tal lei da gravidade"...

\section{Privatização da informação}

Herbert Schiller terá sido um dos raros, quiçá único, pensador marxista a colocar o dedo na ferida do capitalismo nosso contemporâneo: este hoje se organiza econômica, jurídica, ideológica e politicamente em torno da privatização da informação (Schiller, 1986).

Até pouco mais da metade do século passado, boa parte da informação-valor necessária à vida econômica e social era tratada, no geral, como recurso, ou bem, público. Embora, claro, já fossem praticados muitos mecanismos de apropriação, tais como as patentes e o copyright, a maior 
parte da informação social encontrava-se publicamente disponível, sendo acessível a todos, gratuitamente (ou quase), através dos aparelhos de Estado e de outras instituições sociais: escolas, bibliotecas, centros de saúde, organizações governamentais etc. Daí também, os meios de transporte da informação - telecomunicações e radiodifusão - eram igualmente considerados infraestruturas de natureza pública, sendo diretamente controlados pelo Estado na maioria dos países capitalistas centrais (com a notável exceção dos Estados Unidos) e em boa parte dos países periféricos. Aprópria teoria econômica neoclássica, consolidada com Walras e Pareto nas primeiras décadas do século XX, admitia que o "correto" funcionamento dos mercados dependia do livre e igual acesso à informação por parte de todos os agentes (apud Arrow, 1977). O controle da informação por algum agente causaria uma desigualdade na capacidade de ação de todos, impedindo a alocação "ótima" dos investimentos e dos gastos de consumo.

$\mathrm{Na}$ era do capitalismo liberal, a legislação de propriedade intelectual, nascida na Inglaterra no século XVII, estabelecia que os direitos sobre a obra de arte ou sobre a invenção pertenciam, por um determinado prazo, exclusivamente ao autor da obra ou da invenção. O direito era atribuído ao trabalhador individual, servindo como prêmio e estímulo à continuação dos seus trabalhos de criação. Quando emerge, nos primórdios do século XX, o capitalismo monopolista, ou "fordista", promove-se uma revisão daquele princípio, passando-se a atribuir esses direitos à empresa que assalariava o trabalho dos inventores. Essa revisão se deu ao longo de um processo político e jurídico ocorrido nas duas primeiras décadas do século XX e hoje em dia quase esquecido, liderado por engenheiros-capitalistas (a exemplo de Baekeland, Edison, Theodor Vail e outros) e seus porta-vozes nos meios forenses e na imprensa (Noble, 1979). Como esse processo de expropriação dos resultados do trabalho de cientistas e engenheiros teve início e avançava nos Estados Unidos, a europocêntrica liderança intelectual e política socialista sequer tomou conhecimento dele, mais preocupada com o que se passava... na Rússia.

Mesmo assim, os direitos à propriedade intelectual ainda não cobriam a maior parte dos recursos e bens informacionais, mas apenas o objeto material efetivamente produzido e comercializado por uma dada empresa, a partir dos desenhos, modelos, protótipos, etc, desenvolvidos por seus engenheiros e técnicos. Excluíam-se dos direitos à propriedade, as meras idéias que ainda não haviam se concretizado em alguma obra concreta; qualquer forma viva da natureza; os bens claramente culturais etc. Sem falar das informações de natureza e uso público ou social: estatísticas nacionais, por exemplo. 
O avanço da "era da informação" levou à ultrapassagem desses limites. Nas últimas décadas do século XX, de novo a partir dos Estados Unidos, teve início um processo generalizado de ampliação dos direitos à propriedade intelectual, de modo a permitir que grandes corporações capitalistas pudessem açambarcar informações oriundas de manipulação genética, da cultura milenar dos povos, de meras idéias a todo instante geradas na sociedade. Em particular, uma grande ofensiva capitalista foi deslanchada sobre os serviços públicos, depositários que são de um incalculável banco de dados a respeito da sociedade. Esta é a origem e meta da privatização dos serviços de infra-estrutura, de educação, de saúde, de previdência etc, em curso, com maior ou menor perversidade, em todo o mundo capitalista avançado e nas suas periferias mais integradas (Schiller, 1986).

O mesmo papel que, no dizer de Bolaño, cumpre a "audiência" para a realização da produção cultural industrializada, cada grupamento humano (homens, mulheres, idosos, crianças, negros, homossexuais, "verdes" etc, etc), pelas necessidades que gera, emoções que busca, ou ações que produz, cada grupamento humano será fonte de informação-valor para algum tipo de aplicação do capital-informação. Bem entendido: desde que consuma. A sociedade deixa de se distinguir pelas classes reais que a compõem e passa a ser diferenciada pelas "classes" de consumo: as marqueteiras classes "A", "B", "C" etc, ou "negros", ou "gays", ou "mulheres"... No mesmo movimento, a educação, a saúde, a segurança individual ou coletiva, tornam-se frentes de investimento lucrativo, depois de terem sido, por muitas décadas, objeto dos dispêndios sociais. O conhecimento milenar de tribos indígenas primitivas é fonte de informação para a indústria multinacional de medicamentos (Shiva, 2001). O nome de uma operação militar imperialista - "Choque e Terror" - é imediatamente patenteado por uma corporação produtora de jogos eletrônicos. Aimagem - do atleta, do artista, até do político - tudo se transforma em fonte de informação-valor. Sublinhemos, a imagem: isto é, aquilo que o atleta, ou o artista, ou o político, pode significar para as emoções humanas, não o seu corpo, ou os seus atos concretos, meros veículos - suportes - de suas imagens.

$O$ reverso de todo esse movimento de privatização da informação que está na essência destes nossos tempos, foi denunciado por Schiller: "Quando a informação se torna um produto comercial, é a própria informação que é produzida visando o lucro. Quem pode pagar por ela, e quanto ela vai custar tornam-se um assunto que afeta a todos. Quando o critério de poder de compra torna-se o critério padrão para o acesso à informação - e isto é precisamente o que ocorre quando o suprimento e dis- 
seminação da informação passa ao controle de empresas mercantis - as divisões na sociedade se aprofundam. O pobre torna-se ainda mais pobre porque se vê excluído dos meios através dos quais a sua condição poderia ser melhorada. O rico se torna mais rico porque detém os meios para consolidar e expandir as suas bases de poder" (Schiller, 1986: 38-39).

Qualquer indivíduo necessita de informação para assegurar a sua sobrevivência e realizar o seu ser social. Mas, sob o capitalismo, qualquer indivíduo somente logrará assegurar a sua sobrevivência e realizar o seu ser social se buscar e fornecer informação-valor. Para buscá-la, necessita estar dotado das competências necessárias, ou seja, de algum grau de informação passada, ou conhecimento, que lhe permita perceber a informação que deve e pode produzir. Para fornecê-la, necessita estar dotado também de algum grau de conhecimento (informação passada, já adquirida, já trabalhada antes) sobre a informação que pode ser valorizada. Os índios desconhecem o valor informacional do conhecimento que detém sobre as propriedades medicinais das plantas nativas, não por que ignorem essas propriedades, mas porque aquele valor, para o capital, não se realiza em chás e mezinhas, mas em drágeas e xaropes nos quais o trabalho informacional de cientistas as transformam para fins de acumulação. Aquele conhecimento milenar não tem valor para o capital, aliás não tem qualquer valor econômico, exatamente porque é conhecimento passado, equivalente a trabalho morto, informação já processada e objetivada que precisará ser trabalhada para ganhar novo valor. Este valor, realizado em rendas informacionais, será repartido (não eqüitativamente, claro) entre cientistas, investidores, outros agentes da sociedade capitalista, nada sendo devolvido aos índios.

Em resumo, para trabalhar informação-valor, o sujeito precisa oferecer, ao mercado capitalista, um investimento prévio, em formação e capacitação, que lhe garantirá ser empregado por este mesmo mercado capitalista na geração e repartição de rendas informacionais. Quem não dispõe desse investimento inicial, está excluído. Quem dispõe, terá acesso àquele regime de produção e consumo capitalista avançado, onde as "mercadorias" perdem aceleradamente valor, mas o trabalhador-consumidor estará sempre disposto a sustentar um ritmo frenético de trabalho que lhe permita consumir bugigangas fungíveis, umas trás das outras. Lembrando o princípio de Mateus, a riqueza em informação atrai mais riqueza em informação; a pobreza informacional somente evolui para a completa miséria material e cultural.

Daí porque vivemos em uma sociedade global à qual bem se aplicam, tanto nas relações entre as classes sociais, quanto nas relações 
entre os países, as palavras de Anthony Smith: "Será cada vez mais difícil buscar o desenvolvimento econômico em um mundo no qual as maiores forças industriais complementam seus poderes materiais com sofisticados sistemas de informação, através dos quais constantemente reforçam as disparidades entre eles e as sociedades menos desenvolvidas. As sociedades despojadas retrocederão mais e mais à condição de objetos, não de sujeitos da história. Elas serão ainda mais aprisionadas a uma espiral de subinformação do que já o são, hoje. [...] As divisões entre os informacionalmentericos e os informacionalmente-pobres - tanto internacional, quanto nacionalmente - poderão vir a ser ainda mais inexoráveis, de longe mais difíceis de se superar, do que as divisões baseadas na exploração econômica" (Smith, 1980: 113).

\section{A esfera mediática privatizada}

Habermas viu a esfera pública burguesa dar lugar a uma esfera social semipública, traindo os sonhos radicalmente democráticos dos oitocentos. Talvez possamos dizer que nesta nova etapa da evolução do modo capitalista de produção, aquela esfera social habermasiana esteja dando lugar a uma esfera mediática privatizada, traindo os sonhos social-democratas dos novecentos.

Já vimos que os média constituem-se numa das principais, se não a principal, indústria de ponta do século XXI. Na medida em que a informação - e todo o conhecimento e cultura dela derivados e nela embasados - vai sendo incorporada às organizações capitalistas que a transformam em objetos de consumo cultural valorizável e fungível; produzir informação torna-se imbricadamente um processo de produção também do seu produtor, isto é, do trabalhador que, por um lado, valoriza a informação e, ao mesmo tempo, por outro lado, descarta de imediato o objeto informacional comunicado e, nisto, desvalorizado. Donde a produção de "audiências", ou "customização" (em mais um dos anglicismos em moda), não serve apenas à televisão ou ao cinema, mas igualmente à Microsoft, à Coca-Cola, à Nike ou ao laboratório Pfizer ("Viagra"). A produção de "audiências" serve também para eleger um presidente da República, como bem o sabe o publicitário Duda Mendonça...

Se a produção fragmentou-se social-espacialmente, segmentada nas cadeias produtivas mundializadas, como apontamos acima (Parte II, item 1); fragmentam-se também a circulação e o consumo, segmentados nas "audiências" mediáticas das "classes" ou dos "grupos" marqueteiros. A 
totalidade humana, vista nas suas grandes e reais classes sociais, e os sonhos universalistas dela derivados, esfarelam-se na afirmação das "diferenças", dos "localismos", das identidades grupais, subculturais, raciais, sexuais etc. Os média produzem - nas notícias, nos filmes, na publicidade, noutras manifestações jornalísticas ou artísticas que insistem em difundir, e só difundir, como sendo "contemporânea e atual", uma tal fragmentação da humanidade - os média produzem esse caleidoscópio nanosocial, assim como antes produziram um mundo (capitalista) macro-homogêneo. Será através desta mediática "seqüência de momentos sem hierarquia e sem valores" (Genro, 2003: 2) que penetrarão as ideologias "pós-modernas" (Harvey, 1996) dissolvendo as "grandes narrativas". E o espaço público, ou o que dele sobrou, vai sendo assim reduzido a "audiências" e, através delas, sendo também privatizado para efeito de valorização e acumulação. E o que, no espaço público, não serve para esse efeito, é também excluído: excluído da notícia, excluído do entretenimento (exceto, como grotesco, ridículo, não raro humilhante), excluído do consumo. Logo, excluído do trabalho, do emprego, das relações capitalistas de inclusão social.

Evidentemente, os milhões de seres humanos que o capitalismo informacional vem jogando nessa situação abjeta, em todo o mundo, reagem, de um modo ou outro, às condições nas quais vegetam. Tentam ingressar no "paraíso capitalista", migrando para os países centrais e neles sobrevivendo baixo todo o tipo de exploração, violência ou preconceito. Ou preferem afugentar essa miragem, aferrando-se a tradições milenares, em busca de um passado histórico que não pode, porém, deixar de conviver, agressivamente, com o presente. Então, desse autêntico choque civilizatório, o passado irracional se apodera dos instrumentos do presente racional na vã tentativa de impedir que este prossiga rumo ao futuro: e explode espetacularmente, no que acaba sendo mais um show mediático, as imagens de sucesso, poder e ambição do capitalismo informacional são os boeings que a barbárie joga contra as torres da civilização.

\section{PARTE III: EM BUSCA DE NOVA AGENDA}

\section{Está faltando a alternativa}

$\mathrm{Na}$ transição capitalista que se deu ao final do século XIX e primeiras décadas do século $\mathrm{XX}$, dois grandes projetos políticos disputaram a liderança e hegemonia do processo. Um desses projetos orientava-se por 
uma racionalidade teórica explícita, por um corpo doutrinário político-ideológico claro, e dizia abertamente o seu nome: socialista, às vezes, comu nista. Percebia-se predestinado a fundar uma sociedade pós-capitalista mais justa e eqüitativa, e acreditava já estar vivenciando a etapa final da era do capital. AUnião Soviética viria a ser o seu grande laboratório.

O outro programa não parecia estar dotado de alguma racionalidade teórica totalizante, embora não lhe faltassem teorias setoriais: na economia, exprimia-se através da obra neoclássica de Walras, Pareto e outros; na sociologia, pelas idéias de Weber, Durkheim etc. Em alguns campos novos de conhecimento, produzia também corpos teóricos que viriam a se mostrar muito influentes, inclusive não raro causando estragos ou deturpações no pensamento à esquerda: a semiologia estruturalista de Saussure, por exemplo, e sua derivação antropológica em Lévi-Strauss; a ergonomia e a sociologia do trabalho que remontam, mesmo sem ainda assim se definirem, a Taylor e Elton Mayo. Esse segundo programa, cuja concretude prática teve origem na "reestruturação produtiva" liderada por Taylor e Ford, ganhou sua formulação política definitiva no New Deal de Roosevelt, teoricamente legitimado pela heterodoxia socializante de Lord Keynes.

Os dois programas não poderiam fugir às determinações sociais e materiais de sua época histórica. Experimentaram soluções, acertaram algumas vezes, erraram outras, no interior de uma base técnica dada e das condições gerais de vida, inclusive as culturais, do conjunto da população européia e estadunidense de então. Em um caso ou em outro, tratava-se de incorporar milhões e milhões de pessoas a padrões civilizadamente mais elevados de produção e consumo, tanto material quanto espiritual. Nisto, ambos os programas, onde aplicados, lograram relativos êxitos e legaram, para o futuro, importantes problemas, dentre eles o ecológico. ${ }^{2}$

2 O Estado socialista de tipo soviético logrou, sem nenhuma dúvida, introduzindo na produção, em escala nacional e sem espaço a contestações, o mais duro taylor-fordismo, desenvolver aceleradamente a sua indústria e melhorar consideravelmente os padrões básicos de vida das suas populações. Operou o mesmo movimento, também experimentado nos Estados Unidos e na Europa, de incorporação de grandes massas da população aos processos capitalistas de produção e consumo. Não precisou, para isto, do empreendedor privado - antes, pelo contrário. E, na outra ponta, desprezou o trabalhador... consumista. Mesmo assim, no imediato pós-Guerra, a URSS encontrava-se entre os países líderes mundiais nas grandes indústrias da segunda revolução industrial; contava com uma enorme população muito bem educada e finalmente urbanizada; lograra até sair na frente dos demais países desenvolvidos, na corrida espacial. Então estancou. O rígido taylor-fordismo socialista não abria espaço para o necessário salto adiante, aquele que levaria à "revolução da informação". Quando todo o grande ciclo histórico "fordista" ingressou, finalmente, em sua crise sistêmica, nos anos 1970-1980, o bloco socialista, ironicamente, veio a ser a sua mais dramática vítima. Esboroou-se como um castelo de cartas, fazendo tábula rasa de toda a sua tormentosa, mas gloriosa, história ainda recentemente passada. 
Entre esses dois programas existia uma grande diferença que não podemos, não devemos, nem queremos escamotear: o programa que viria a ter no capitalismo estadunidense o seu melhor paradigma, valorizava o individualismo e a democratização do acesso aos bens materiais como medidas de melhoria pessoal e de progresso social; o outro, cujo paradigma seria o socialismo soviético, valorizava a solidariedade coletiva e a democratização do acesso aos bens culturais como medidas de melhoria pessoal e progresso social. Eram estas, e sempre foram estas, as grandes e decisivas diferenças entre o compromisso capitalista e o compromisso socialista - diferenças éticas.

Fora isto, as bases materiais e sociais disponíveis no século XX não continham ainda um amplo conjunto de elementos que permitisse a qualquer experimento socialista avançar para uma organização "comunista [dirigida] contra o modo anterior de atividade [que] elimina o trabalho, e suprime dominação de classes [etc]" (Marx, 1973: 81, grifos meus - M. D.). No limite, o socialismo modelado na União Soviética não poderia ainda romper com as relações de trabalho tal qual também existiam nos Estados Unidos e na Europa Ocidental, mesmo tendo eliminado o "patrão". É que não era este o fulcro do problema. Por isto, o modelo soviético acabou depravando o ideal socialista em um tipo de regime político-estatal autoritário, pára-autárquico, efetivamente opressor. Tudo ao contrário do que, inicialmente, prometera.

Foi pela estrada dita "capitalista" que mais longe se chegou a uma nova etapa histórica que nos permita associar uma organização solidária e democraticamente culta da produção e da sociedade, com uma existência libertada do trabalho. Tal não significa dizer que o ser humano vá se liberar das atividades produtivas, criadoras de riqueza. Mas já não necessita exercê-las sob as limitações e desgastes próprios ao trabalho rotineiro e repetitivo. Qualquer trabalho, ou melhor, qualquer atividade pode, agora, tentar alcançar aquela dimensão "realmente livre", mas ainda "condenadamente séria, exigindo o mais intenso dos esforços", própria da produção artística, que Marx previa para um futuro pós-capitalista (Marx, 1971: V. 2, p. 120). Esta é a exata conseqüência de uma evolução que sintetizou o valor do trabalho na sua dimensão concreta, superando a abstrata. Para que, no entanto, esta atividade concreta viesse a se tornar não apenas central mas, sobretudo, amplamente dominante no conjunto do tecido social contemporâneo, ainda haveria que nos libertarmos da alienação embutida na propriedade privada. Paradoxalmente, ao chegarmos neste estágio civilizatório, nunca a apropriação privada da riqueza social foi tão intensa, tão 
abrangente, tão capilar. Privatizando a informação, o capitalismo deu um verdadeiro golpe nos nossos melhores sonhos de justiça, eqüidade, solidariedade e enriquecimento cultural. Conquistou uma vitória aparentemente tão completa que a privatização da informação vem acontecendo sem que, até agora, a esquerda socialista tenha, teórica e politicamente, colocado esta questão na primeira linha da sua agenda programática.

Nesta virada do século XX para o XXI, não contamos mais com dois programas teórico-políticos disputando a hegemonia dos movimentos da sociedade. Há um programa individualista e materialista em pleno curso, sob o rótulo de "projeto neoliberal". Ora, este projeto, quando o observamos na sua necessária relação com as estruturas socioeconômicas mais profundas, não passa de expressão, no plano das idéias, da evolução capitalista nesta nova etapa, tanto quanto, nas primeiras décadas do século passado, a inclusão de massas de trabalhadores em condições mais avançadas de produção e consumo acabaria por resultar no que poderíamos denominar "projeto keynesiano", expressão da evolução capitalista naquela etapa. Mas se este "projeto keynesiano" confrontava-se com uma alternativa teórica, política e ideológica de esquerda, socialista, o atual "projeto neoliberal" não enfrenta um oponente teórico, político e ideológico à sua altura. Ainda não construímos um projeto que seja capaz de levar adiante o propósito civilizatório de elevação do padrão geral de produção e consumo, tanto material quanto espiritual, das massas, apoiado na nova base técnica e cultural da atual etapa histórica.

No entanto, exatamente porque o capitalismo fez da informação, em definitivo, a sua fonte de valorização e produção de riquezas, exatamente por isto, agora sim, podemos dizer que o capitalismo atingiu a sua etapa superior na qual: $i$ ) os tempos de circulação monetária e de comunicação da informação estão reduzidos aos limites de zero, graças às tecnologias digitais; ii) o tempo de circulação das mercadorias materiais está reduzido ao mínimo irredutível, face às suas determinações físico-materiais, e, por isto mesmo, foi descolado do tempo de circulação monetária e de comunicação da informação; donde, iii) como o capital se valoriza na anulação do tempo, é nas atividades que se realizam num tempo no limite de zero que se encontram as fronteiras da acumulação e as novas frentes de desenvolvimento do capitalismo. Daí a "financeirização" e "informacionalização" do capitalismo.

Não vamos, com isto, pretender que o capitalismo viva os seus estertores. Longe disso! Ainda teremos uma longa caminhada pela frente, até que a humanidade logre construir uma alternativa social e econômica 
que lhe permita, com base na informação, fundar aquela sociedade na qual "toda a produção [possa] concentrar-se nas mãos dos indivíduos associados" (Marx e Engels, 1988: 87). Sequer vislumbramos muito bem, hoje em dia, a forma que esta sociedade deverá tomar. É diferente daqueles tempos bolcheviques. Antes mesmo de eclodir 1917, O Planeta Vermelho de Bogdânov já descrevia, com boa dose de acerto, como seria (otimisticamente) a futura União Soviética (apud Scherrer, 1986).

Essa, porém, é a menor das diferenças entre as nossas condições políticas de hoje e aquelas de cem anos atrás. Mais decisivo será perceber que justo agora quando a inclusão social foi abandonada pelo programa capitalista, e exatamente porque foi por ele abandonada, justo agora incorporar milhões de homens e mulheres a padrões superiores de produção e consumo se impõe como bandeira maior do programa socialista. Por outro lado, não cabe mais buscar, enquanto projeto estruturante, a inclusão social através de uma organização socioeconômica baseada na produção e no consumo padronizado de massas, de tipo "fordista" nem, na outra ponta, através de alguma organização "familiar" da produção e do consumo que parece nos remeter a alguma utopia "franciscana" de vida, digamos assim. Se dispomos de uma base técnica que permite liberar trabalho rotineiro e repetitivo, esta mesma base técnica permite libertar as forças culturalmente criativas da sociedade dos estreitos limites e da repressão que lhes impõe a privatização capitalista da informação. Um exemplo desse conflito latente é a disputa social e política que já se trava entre os adeptos dos programas proprietários e os dos programas livres de computador. Enquanto os programas proprietários tendem a coagular a informática e a microeletrônica em torno de um punhado de grandes corporações empresariais, Microsoft à frente; os programas livres tendem a multiplicar o número de pequenos $\mathrm{e}$ médios produtores independentes, processo que, se politicamente orientado, poderia ser um exemplo a apontar para aquela "sociedade de indivíduos associados" à qual Marx e Engels se referiam no seu Manifesto.

Outra disputa envolvendo a livre informação e a informação proprietária (e os livres produtores vs. os produtores alienados) dá-se em torno do "Napster" e outros programas semelhantes. Eles permitem que as pessoas troquem, entre si, produtos audiovisuais através da rede mundial de computadores, sem que ninguém ganhe qualquer centavo com isso. São presentes dados e recebidos por pessoas que nunca se viram, nem se conhecem, mas se demonstram solidárias com os desejos culturais de um outro qualquer. Assim fazendo, elas reduzem definitivamente a zero o valor das "mercadorias" culturais comercializadas por gravadoras fonográficas, 
estúdios cinematográficos etc. Trata-se de mais uma demonstração cabal da inviabilidade prática de uma economia capitalista da informação, conforme discutimos na Parte II, item 3, acima. Em seu lugar, estaria nascendo, em um movimento espontâneo da sociedade, uma "economia de presentes" (gift economy), no dizer de Barbrooke (1999), que lembraria o pot lach praticado por indígenas melanésios. É claro que o capital não poderia assistir a um tal fenômeno de braços cruzados. Mas enquanto se observa uma vigorosa ofensiva jurídica da indústria fonográfica e dos média contra esses promotores do comunismo cibernético, não se percebe, na esquerda, qualquer mobilização maior em defesa do livre acesso à informação, que proponha um novo pacto entre produtores e usuários capaz de garantir a necessária remuneração do trabalho (de músicos, artistas etc) sem obrigatoriamente gerar mais-valia para o capital.

Poder-se-ia também denunciar a biopirataria como outra frente de apropriação da informação e exclusão social (Shiva, 2001). Também nesta frente, como em tudo o mais que se refira à saúde e à educação das populações, ainda se está por formular projetos que garantam a produção e disseminação de informação necessária ao bem-estar e riqueza da sociedade, sem que disto resultem, por um lado, a inclusão da minoria já incluída, e, por muitos lados, a exclusão da maioria já excluída. No entanto, é tão indecente esse uso mercantil da saúde humana que até governos no geral neoliberais, como o foi o governo Cardoso, propuseram-se a enfrentar as multinacionais dos remédios, defendendo a quebra de suas patentes pelo menos nas situações mais indecorosas, como nos medicamentos para a sida ("aids").

Como disse Schiller, "em muitas lutas futuras, informação e comunicação serão esferas decisivas de contestação" (Schiller, 1986: 125). O terreno dessas lutas, pela própria natureza delas, são os meios de comu nicação. Se o capital, nesta nova etapa, avança através dos média privatizados, não vamos lograr enfrentar e superar a fragmentação mediática, se não formos capazes de construir (ou reconstruir) uma rede pública de comunicação a serviço do humanismo universalista, um humanismo não apenas não-discriminatório mas, também, antidiscriminalizante.

Já se sabe, desde Nora e Minc (1978), que as redes teleinformatizadas permitiriam a edificação de uma ágora informacional que possibilitaria às comunidades e cidadãos se encontrarem enquanto público que debate e decide idéias e projetos no interesse de todos. De fato, a democratização da esfera pública não terá sido inviabilizada apenas pela própria evolução capitalista, mas também por um obstáculo de difícil superação: o 
espaço. A ágora antiga era viável em cidades-estados pequenas e de populações minúsculas, considerando nossos padrões atuais. Já os modernos estados-nações, por suas próprias dimensões, não fossem outros fatores, tornariam muito difícil outra forma de expressão política popular que não através de alguma representação delegada. Se o capital, para se valorizar, necessitava anular o espaço através do tempo; a democracia, para se viabilizar, também necessitaria avançar na mesma direção. Mas se o capital investiu na solução daquele seu problema, os democratas não investiram na resolução deste. As tecnologias de informação e comunicação que poderiam ter servido à radicalização da democracia, como, por exemplo, as primeiras experiências radiofônicas nos primórdios do século $\mathrm{XX}$, acabaram evoluindo rumo ao fortalecimento do mercado e à centralização do poder (Dantas, 1996b). São fortes os indicadores de que, novamente agora, estando construída uma rede mundial de computadores que tem servido à participação política "anárquica" dos indivíduos e à expansão de uma "economia de presentes", novamente agora concentram-se as forças do capital em um esforço para dar a essa rede um rumo meramente mercantil, a serviço da apropriação privada da informação e da produção frag mentada do consumo e da vida.

Grupos mediáticos edificam grandes "portais" de acesso a sítios da Internet, hospedando ou facilitando o acesso àqueles sítios que sejam obviamente mais lucrativos, isto é, melhor atendam à publicidade e às vendas. Como já acontecera antes, na evolução do rádio e da televisão, os usuários da rede não são estimulados a gerarem os seus próprios conteúdos, mas a apenas reagirem aos conteúdos previamente produzidos pelos "portais". É claro que a atitude desses usuários de "portais" não pode ser meramente passiva, como a dos rádio-ouvintes ou a dos telespectadores, dada a própria definição interativa da rede. Mas se são estimulados a participar, são sutilmente orientados a permanecerem nos limites de uma "cesta" cultural que sirva, direta e indiretamente, à valorização e acumulação do capital-informação. Ao mesmo tempo, ou melhor, no mesmo tempo, enquanto navegam através de "banners" e "links", têm perscrutados os seus gostos, interesses, valores... e gastos médios a cada compra. A internet permite ao capital individualizar o consumidor e dele extrair toda a informação-valor que puder, levando a um limite nuclear a fragmentação social e a concomitante exclusão. "Onde antes se dispunham apenas de vagas médias estatísticas, hoje é possível, a partir de bases de dados reunidas pelos sistemas de informação e com a ajuda de sistemas de inteligência artificial, obter uma categorização individual e precisa de cada 
cliente potencial, determinando instantaneamente se ele representa, ou não, um negócio lucrativo. Pode recusar imediatamente conta ou crédito não só ao cliente inadimplente, como também àquele cujo perfil indica que não investirá ou consumirá em escala suficiente para ser lucrativo, enquanto aqueles potencialmente mais lucrativos serão inundados de malas diretas personalizadas" (“Grandes irmãos", Carta Capital, 16/02/2000).

Se o projeto dos primeiros socialistas tinha por meta a radicalização da democracia, e se, nesta nova etapa, também neste tópico essencial, estão dadas as bases técnicas da sua consecução, então esta será, talvez, a principal frente a ser atacada. Há que se lutar pela construção de uma rede pública de informática e telecomunicações que seja não apenas, e menos, um meio técnico a serviço da sociedade, mas sobretudo um meio de produção de conteúdos comunitários e cidadãos - um espaço onde a informação possa circular como presente e, não, como valor. Assim ainda é, em parte, a Internet. Mas desde que nos esqueçamos dos custos das contas telefônicas, dos custos ainda maiores dos serviços banda-larga, dos custos adicionais dos provedores de acesso e, sobretudo, dos altos custos dos computadores e seus programas, hoje em dia submetidos ao monopólio mundial da dupla Intel-Microsoft. Uma rede pública de acesso à informação e à cultura terá custos, claro; mas custos socialmente rateados, cabendo o peso maior dessa conta aos mais ricos, em benefício dos mais pobres.

\section{O agente da mudança}

Ao finalizarmos este texto, precisamos enfrentar uma questão crucial: quem é o agente social que pode liderar o processo? Ainda há quem pense nas potencialidades da classe operária, ignorando que esta classe operária, quando vista como vanguarda da revolução, era de fato um grupo social poderoso mas interessado, principalmente, em amealhar parcelas maiores da mais-valia social geral, conforme discutimos na Parte I deste texto. Das lutas, muitas vezes heróicas, que travou, resultaram os pactos sociais que sustentaram o acelerado desenvolvimento capitalista (e, também, socialista) dos anos 1930 a 1970. Como Gorender reconheceu, "o proletariado não constitui um corpo estranho na estrutura socioeconômica burguesa, porém a integra normalmente" (Gorender, 1999: 39).

Há quem, diante deste óbvio impasse, busque alternativas em uma "classe-que-vive-do-trabalho" (Antunes, 2000). Ora, na era da informação, todas as classes vivem do trabalho, exceto, talvez, aquelas exclusivamente rentistas e financistas. Sendo o trabalho de natureza informa- 
cional; sendo o valor do trabalho fornecido pelo valor da informação gerada e comunicada; sendo este valor, ainda por cima, trabalho concreto não redutível a trabalho abstrato, o trabalhador contemporâneo é todo aquele que produz e consome diretamente capital, embora, nesta produção e neste consumo possa ocupar degraus muito diferenciados na escada social. $\mathrm{O}$ mais rico, aí, não é menos trabalhador do que o mais pobre. Nem este mais pobre estará, necessariamente, mais propenso à revolução. Não raro, são os estratos sociais desfavorecidos que mais buscam no fundamentalismo religioso, inclusive evangélico, ou na barbárie definitiva (seja etnicoterrorista, seja narcoterrorista), uma alternativa, embora inviável, para o estado de miséria material e moral em que se encontram.

$\mathrm{O}$ agente da transformação é o sujeito social que está à frente do progresso material e cultural. Voltando ao início deste texto, o agente da transformação é quem detém o conhecimento produtivo necessário para impulsionar a geração de riquezas e a democratização da sociedade. Marx viu este agente no trabalhador assalariado "adulto" semi-artesão do seu tempo. Kautski, Lenin e seus contemporâneos não perceberam que o deslocamento do conhecimento produtivo para uma esfera de trabalho externa à fábrica não negava, pelo contrário, a teoria de Marx, mas lhe cobrava outros desdobramentos. De qualquer modo, o peso quantitativo e político do operariado fabril, na primeira metade do século XX, pareceu dar razão a gerações de marxistas ao longo do século passado. Hoje em dia, precisamos reconhecer que os agentes da transformação são todos aqueles que, trabalhando com o conhecimento obtido do processamento técnicocientífico da informação, põem em questão, um tanto conscientemente, um tanto espontaneamente, os arranjos capitalistas de apropriação privada dessa nova e extraordinária forma de riqueza. Disse-o Lojkine: "Tais atores, de alguma maneira, somos todos nós, conscientemente ou não, promotores de novas cooperações entre indústrias e serviços - como o foram, no passado, todos os usuários de máquinas-ferramentas, confrontados com as suas potencialidade contraditórias (e, pois, com opções que estavam longe de serem puramente técnicas)" (Lojkine, 1995: 309-310).

Boa parte desses "nós", no Brasil, ajudou a eleger Lula presidente. Oxalá possamos agora experimentar nossos projetos de "software" livre, governo eletrônico, desenvolvimento ambiental sustentável, combate à biopirataria, democratização das comunicações, educação de qualidade para todos, universalização do acesso às telecomunicações e à Internet etc. É por aí que faremos a inclusão social e, quiçá, lançaremos as bases de um novo programa socialista, agora democrático. Precisamos dar a vara de 
pesca ao faminto, e o conhecimento para pescar. Pouco avançaremos, dando-lhe apenas um peixinho para comer a cada dia...

MARCOS DANTAS é professor do Departamento de Comunicação da PUC-RJ; atualmente secretário de Planejamento, Orçamento e Administração do Ministério das Comunicações.

\section{REFERÊNCIAS BIBLIOGRÁFICAS}

ADORNO, Theodor W. e HORKHEIMER, Max (1985 [1969][1944]). Dialética do esclare cimento. Rio de Janeiro: Jorge Zahar Editor.

ANTUNES, Ricardo (2000). Os sentidos do trabalho. São Paulo: Boitempo Editorial, $3^{\text {a }}$ ed. ARRIGHI, Giovanni (1996). O longo século XX. Rio de Janeiro: Contraponto Editora.

ARROW, Kenneth J. (1977). Bienestar económico y asignación de recursos a la invención. In: Lamberton, D. M. (Org.), Economia de la información y del conocimiento. Mexico: Fonde de Cultura Económica, pags. 137-153.

ATLAN, Henri (1992 [1979]). Entre o cristal e a fumaça. Rio de Janeiro: Jorge Zahar Editores.

BAKHTIN, Mikhail (V. N. Volochinov) (1986 [1977] [1929]). Marxismo e filosofia da lin guagem. São Paulo: Editora Hucitec.

BARBROOKE, Richard (1999). Manifesto Cibercomunista, Folha de S. Paulo, Caderno "Mais", pags 4-6, 3/10/1999.

BATESON, Gregory (1998 [1972]). Pasos hacia una ecologia de la mente. Buenos Aires: Ediciones Lohlé-Lumem.

BELL, Daniel (1976 [1973]). El advenimiento de la sociedad post-industrial. Madri: Alianza Editorial.

BESSANT, John (1990). Fifth wave manufacturing: the management implications of new manufacturing technology, Center for Business Research, Brighton Politechnic, R.U.

BOLAÑO, Cesar (2000). Indústria cultural, informação e capitalismo. São Paulo: Editora Hucitec-Editora Pólis.

BRETTON, Philippe (1991 [1987]). História da Informática. São Paulo: Editora da Unesp. BRILLOUIN, Léon (1988 [1959] [1956]). La science et la Théorie de l'Information. Paris: Éditions Jacques Gabay.

BURAWOY, Michael (1979). Manufacturing consent. Chicago: The University of Chicago. CASTELS, Manuel (1998 [1996]). La societé en réseaux. Paris: Librairie Arthème Fayard.

CARAÇA, João (1993). Do saber ao fazer: porque organizar a ciência. Lisboa: Gradiva Publicações.

CHANDLER, Alfred (1977). The visible hand: the managerial revolution in American Business, Cambridge: The Belknap Press.

CSE MICROELECTRONICS GROUP (1980). Microelectronics: capitalist technology and working class. Londres: CSE Books.

DANTAS, Marcos (1994). Trabalho com informação: investigação inicial para um estudo na Teoria do Valor, Dissertação de Mestrado, ECO-UFRJ, Rio de Janeiro, RJ, (1996b). Alógica do capital-informação, Editora Contraponto, Rio de Janeiro, RJ. (1999). "Capitalismo na Era das Redes: trabalho, informação, valor no ciclo da comunicação produtiva", in: LASTRES, H e ALBAGLI, S., Informação e glo - 
balização na Era do Conhecimento, Editora Campus, Rio de Janeiro, RJ, pags. 216-161.

(2000). "Valor da informação: trabalho e apropriação no capitalismo contemporâneo", Lugar Comum, set. 1999/abr. 2000, NEPCOM/ECO-UFRJ, Rio de Janeiro, RJ, pags.91-122.

(2001a). Os significados do trabalho: uma investigação semiótica no processo de produção, Tese de Doutoramento, COPPE-UFRJ, Rio de Janeiro, RJ, 581 pags.

(2001b) L' information et le travail: la valorization et l' accumulation dans le cycle de la communication productive. In: AZAÏS et alii, Vers un capitalisme cognitif, pags. 76-89, L'Harmattan, Paris, FR.

(2002) Información, capital y trabajo: valorización y apropiación en el ciclo de la comunicación productiva, Escribania, pags.21-48, Universidade de Manizales, jul-dez 2002.

DOBB, Maurice (1965 [1963]). A evolução do capitalismo. Rio de Janeiro: Zahar Editores.

ESCARPIT, Robert (1991). L'information et la communication. Paris: Hachette Livre.

GENRO, Tarso (2003). Demarcação e hegemonia, memo.

GORENDER, Jacob (1999). Marxismo sem utopia. São Paulo: Editora Ática.

GORZ, André (1982 [1980]). Adeus ao proletariado. Rio de Janeiro: Ed. Forense Universitária.

HABERMAS, Jurgen (1986). L'espace public. Paris: Payot.

HARVEY, David (1996 [1989]), Condição pós-moderna. São Paulo: Edições Loyola.

HOBSBAWM, Eric (1997). A Era das Revoluções. São Paulo: Paz \& Terra. (1988). A Era dos Impérios. São Paulo: Paz \& Terra, $3^{\mathrm{a}}$ ed.

(1986 - ) História do Marxismo, vários volumes. Rio de Janeiro: Paz \& Terra. LANDES, David S.(1994 [1969]). Prometeu desacorrentado. Editora Nova Fronteira: Rio de Janeiro.

LAZZARATO, Maurizio (1992). Le concept de travail immatériel: la Grande Entreprise. In Futur antérieur, pp. 54-61, L'Harmattan, Paris, FR.

LENIN, V. I. (1980 [1918]). "As tarefas imediatas do Poder Soviético", in LENIN, V. I. (1980), Obras Escolhidas, 3 vols. São Paulo: Editora Alfa-Omega.

LOJKINE, Jean (1995 [1995]). A revolução informacional. São Paulo: Cortez Editora.

MARX, Karl (1983 [1867]). O Capital: crítica da Economia Política, São Paulo: Abril S. A. Cultural.

(s/d [1969]. Capítulo VI Inédito de O Capital. São Paulo: Editora Moraes. (1971 [1953]). Elementos fundamentales para la crítica de la economia política (borrador) 1857-1858. Siglo Veintiuno Argentina Editores.

MARX, K. e ENGELS, F. (1973 [1932]). La ideologia alemana. Buenos Aires: Ediciones Pueblos Unidos.

(1988 [1848]). Manifesto do Partido Comunista. Petrópolis, RJ: Editora Vozes.

MAZZUCCHELLI, Frederico (1985). A contradição em processo. São Paulo: Editora Brasiliense.

MIZRAHI, Jean (1986). L'échiquier de l'électronique. Paris: Hachette.

NOBLE, David (1979). America by design. Oxford: Oxford University Press. (1986). Forces of production. Oxford: Oxford University Press.

NORA, Simon e MINC, Alain (1978). L'informatization de la societé. Paris: La Documentation Française.

PEREZ, Carlota (1986). Las nuevas tecnologias: uma visión de conjunto. In: OMINAMI, Carlos (Org.), La tercera revolución industrial, GEL.

ROSDOLSKY, Roman (2001 [1968]). Gênese e estrutura de O Capital de Karl Marx. Rio de Janeiro: Editora Contraponto. 
ROSSI, Paolo (1989). Os filósofos e as máquinas. São Paulo: Companhia das Letras.

SCHILLER, Herbert I. (1986). Information and the crisis economy. Nova York: Oxford University Press.

SHANNON, C. e WEAVER, W (1975 [1949]). A teoria matemática da comunicação. Rio de Janeiro: Difel.

SHIVA, Vandana (2001). Biopirataria. Rio de Janeiro: Editora Vozes.

SINGER, Paul (1999). Uma utopia militante. Petrópolis, RJ: Editora Vozes, $2^{\text {a }}$ ed.

SMITH, Anthony (1980). The geopolitics of information: how Western culture dominates the World. Nova York: Oxford University Press.

SCHERRER, Jutta (1986). Bogdânov e Lênin, o bolshevismo na encruzilhada. In: HOBSBAWN, Eric, História do Marxismo, Vol. 3., Rio de Janeiro: Paz \& Terra, pags. 189-242.

SWEEZY, Paul M. (1982 [1956] [1942]) Teoria do desenvolvimento capitalista. Rio de Janeiro: Zahar Editores, $6^{\mathrm{a}}$ ed.

TAYLOR, Frederick W. (1990 [1911]). Princípios de Administração Científica. São Paulo: Editora Ática.

TOURAINE, Alain (1988 [1980]). O Pós-socialismo. São Paulo: Editora Brasiliense.

WIENER, Norbert (1978 [1954] [1950]). Cibernética e sociedade, o uso humano de seres humanos. São Paulo: Editora Cultrix. 